\title{
Research on the Impact of Reclamation Project on the Marine Environment in the Dongjiang Area of Tianjin Port
}

\author{
Liu Bin ${ }^{1}$, and Wang Ning ${ }^{1, *}$, Zhang Wanying ${ }^{1}$ \\ ${ }^{1}$ Laboratory of Waterway Environmental Protection Technology, Tianjin Research Institute For Water Transport Engineering, Tianjin \\ 300456, Chinas
}

\begin{abstract}
With the development of cities and the continuous expansion of human activities, the impact of humans on nature has gradually become prominent. After the Industrial Revolution, the relationship between humans and nature has undergone a subtle change. Whether human beings actively interfere with nature or unconsciously influence the natural environment through behavioral facts, the progress of many human societies is accompanied by the consumption and damage of natural energy. At the same time, nature is also using facts to remind humans that the environmental degradation caused by excessive intervention will eventually affect humans themselves. This study collected 2003, 2012, 2016, and 2019 survey data of seawater quality and ecological environment near the Tianjin Dongjiang Port area. Through a single factor analysis method, we found that the marine environment changes in this area in recent years. The development of Tianjin's urban area is closely related to the development of the port. At the same time, the sea reclamation project in Dongjiang may also be one of the reasons for this change.
\end{abstract}

\section{INTRODUCTION}

Tianjin Port is located in Binhaixinqu, Tianjin, China. It is located at the western of the Bohai Bay. In 1860, Tianjin Port opened to the outside world and became a commercial port. In October, 1952, Tianjin Port reopened. In recent years, the problem of the deterioration of the marine environment in the Bohai Bay has always existed. The reasons may lie in the following aspects. First, the Bohai is semi-closed inland sea, the water exchange capacity is average, and pollutants are relatively difficult to spread.

The second, Bohai coasts have a high degree of urbanization. With rapid development in recent decades, cities have expanded rapidly, and discharged a lot of waste.

The last, Bohai are rich in mineral resources such as oil, with large fish production and a vigorous breeding industry. At the same time, the development of port transportation has also led to a decline in marine water quality.

The Dongjiang Port Reclamation has been implemented since 2002. The first to be implemented was the Beida Breakwater Project. By the end of 2004, the north breakwater, west breakwater and south breakwater of the Beida Breakwater Project were completed. Construction of the outer north breakwater has not yet started. By the end of 2004, the southern contour of Dongjiang Port Reclamation had basically been formed, and the actual reclamation had not yet been formed.
By the end of 2006, a part of the inner wall of the Beida Breakwater Project was completed. The wall, together with the north breakwater, the west breakwater, the outer south breakwater, formed a reclamation of 1731.8 hectares; until 2009, the Beida Breakwater Project continued to be implemented This resulted in the reclamation area of about 2600 hectares; by 2011, the reclamation area was about 3200 hectares; by 2013 , the reclamation area was about 3300 hectares. Since 2014, there has been no change in the boundary line of Dongjiang Port Reclamation, and there has been no new encirclement and reclamation.

According to the analysis of statistical results, the period from 2005 to 2013 was the stage of large-scale reclamation in the Dongjiang Port, and there was no new reclamation after 2014.

Our research collected the survey data of in the past ten years, and compared the changes in the water environment near the Dongjiang Port in the Bohai Bay, providing a basis for Bohai Bay ecological management and research.

\section{MATERIALS AND METHODS}

\subsection{Monitoring data}

In order to fully assess the environmental changes in the sea area before and after the Dongjiang Port Reclamation, and evaluate and analyze the degree of marine environmental changes in the sea area where the project is located, the assessment data shall be screened

* Corresponding author: 15674457@qq.com 
according to the following principles that the survey time is before, during and after reclamation construction, and the survey try to in the same season

According to the time and space characteristics of Dongjiang Port Reclamation, the data from 2003, 2012, 2016, and S 2019 are used as autumn monitoring data before, during and after the construction of the Dongjiang Port reclamation, and the monitoring data in the autumn are summarized. Analyze the environmental quality of the sea area where reclamation is located.

This study collected the survey data of water quality and marine ecology at autumn in 2003, 2012, 2016 and 2019. The list of data sources is shown in Table 1 .

Table 1. Monitoring points in each year.

\begin{tabular}{|c|c|c|c|}
\hline Time & $\begin{array}{c}\text { The } \\
\text { numbers } \\
\text { of } \\
\text { Survey }\end{array}$ & Agency & Data Sources \\
\hline $\begin{array}{c}2003 . \\
10\end{array}$ & 22 & $\begin{array}{c}\text { Qingdao } \\
\text { Huanhai } \\
\text { Marine } \\
\text { Engineering } \\
\text { Prospecting } \\
\text { Institute, } \\
\text { Tianjin Marine } \\
\text { Environmental } \\
\text { Monitoring } \\
\text { Central Station }\end{array}$ & $\begin{array}{c}\text { Dynamic } \\
\text { monitoring report } \\
\text { on sea area use of } \\
\text { Tianjin Port Beida } \\
\text { Breakwater Project } \\
\text { Breakwater } \\
\text { Tracking and } \\
\text { Monitoring of } \\
\text { Tianjin Port Beida }\end{array}$ \\
\hline $\begin{array}{c}2012 . \\
10\end{array}$ & 22 & $\begin{array}{c}\text { Tianjin } \\
\text { University of } \\
\text { Science\&Tech } \\
\text { nology }\end{array}$ & $\begin{array}{c}\text { Tianjin Port East } \\
\text { Xinjiang Second } \\
\text { Island Division } \\
\text { Planning } \\
\text { Environmental } \\
\text { Impact Report }\end{array}$ \\
\hline $\begin{array}{c}2016 . \\
10\end{array}$ & 36 & $\begin{array}{c}\text { Tianjin } \\
\text { University of } \\
\text { Science\&Tech } \\
\text { nology }\end{array}$ & $\begin{array}{c}\text { Marine } \\
\text { Environmental } \\
\text { Impact Assessment } \\
\text { Report of Tianjin } \\
\text { Lingang Economic } \\
\text { Zone Marine High- } \\
\text { end Engineering } \\
\text { Equipment } \\
\text { Manufacturing and } \\
\text { Supporting } \\
\text { Industrial Service } \\
\text { Base Project }\end{array}$ \\
\hline $\begin{array}{c}2019 . \\
9\end{array}$ & 24 & $\begin{array}{c}\text { Tianjin } \\
\text { Research } \\
\text { Institute for } \\
\text { Water } \\
\text { Transport } \\
\text { Engineering, } \\
\text { M.O.T }\end{array}$ & $\begin{array}{l}\text { Monitoring Report } \\
\text { on Marine } \\
\text { Environment } \\
\text { Status of Tianjin } \\
\text { Port Container } \\
\text { Terminal }\end{array}$ \\
\hline
\end{tabular}

\subsection{Research methods}

The single factor analysis is the method of this Data analysis in our research. Water quality survey factors include COD, oil, inorganic nitrogen, phosphate, suspended solids, $\mathrm{Hg}, \mathrm{Cu}, \mathrm{Pb}, \mathrm{Zn}$, Se, and Cd. Ecoenvironment survey factors are chlorophyll, Zooplankton biomass and benthic biomass.

\section{RESULTS AND DISCUSSION}

In the survey years, the highest COD content was in 2012, the average COD concentration at each station was about $3.2 \mathrm{mg} / \mathrm{L}$, followed by 2019 , the COD content was about $2.3 \mathrm{mg} / \mathrm{L}$, and the remaining years were below $1.5 \mathrm{mg} / \mathrm{L}$. The maximum content of oil, inorganic nitrogen, and phosphate all appeared in 2016, with average values of approximately $94 \mu \mathrm{g} / \mathrm{L}, 680 \mu \mathrm{g} / \mathrm{L}$, and $52 \mu \mathrm{g} / \mathrm{L}$, respectively. The maximum content of suspended solids appeared in 2003 with an average content of about $56 \mu \mathrm{g} / \mathrm{L}$, and other were all below 25 $\mu \mathrm{g} / \mathrm{L}$. The maximum $\mathrm{Hg}$ content appeared in 2012 with an average content of about $0.11 \mu \mathrm{g} / \mathrm{L}$, and other were around $0.05 \mu \mathrm{g} / \mathrm{L}$ and below. The $\mathrm{Cu}$ content was higher in 2012 and 2003, with average content of about 3.8 $\mu \mathrm{g} / \mathrm{L}$ and $3.6 \mu \mathrm{g} / \mathrm{L}$, respectively. The content of $\mathrm{Pb}$ was higher in 2012, about $2.9 \mu \mathrm{g} / \mathrm{L}$, and it was relatively stable in other years. The content of $\mathrm{Se}$ and $\mathrm{Cd}$ was slightly smaller in each survey year, and the average values were below $3 \mu \mathrm{g} / \mathrm{L}$ and $0.4 \mu \mathrm{g} / \mathrm{L}$, respectively. The $\mathrm{Zn}$ content was slightly higher in 2019 , followed by 2016 and 2003, with average content of about $27 \mu \mathrm{g} / \mathrm{L}$, $23 \mu \mathrm{g} / \mathrm{L}$, and $21 \mu \mathrm{g} / \mathrm{L}$, respectively.

In terms of marine ecological environment, the maximum chlorophyll content appeared in 2019, about $7.8 \mathrm{mg} / \mathrm{m}^{3}$, and the minimum appeared in 2012, about $2.8 \mathrm{mg} / \mathrm{m}^{3}$. The maximum value of zooplankton biomass appeared in 2003, which was about $378.8 \mathrm{mg} / \mathrm{m}^{3}$, and it was less in 2012 and 2016 , about $105.7 \mathrm{mg} / \mathrm{m}^{3}$ and 126.1 $\mathrm{mg} / \mathrm{m}^{3}$, respectively. The benthic biomass increased gradually in the survey years, with the lowest value being about $8.88 \mathrm{mg} / \mathrm{m}^{3}$ in 2003 and the maximum value being $29.51 \mathrm{mg} / \mathrm{m}^{3}$ in 2019 .
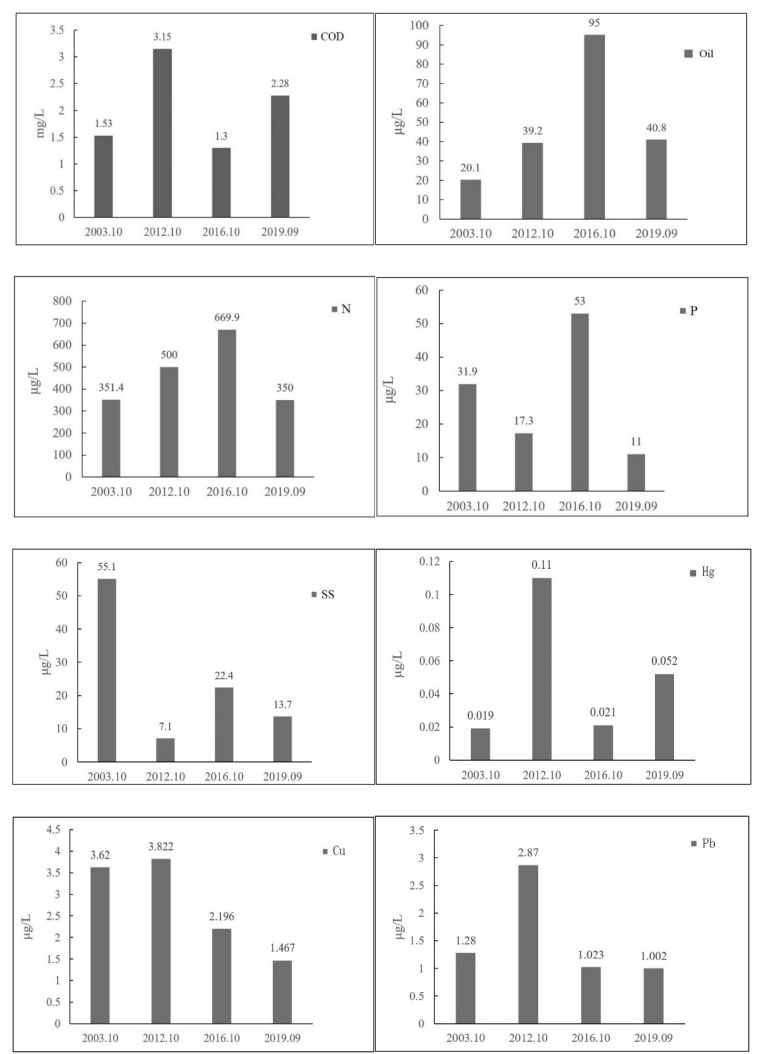

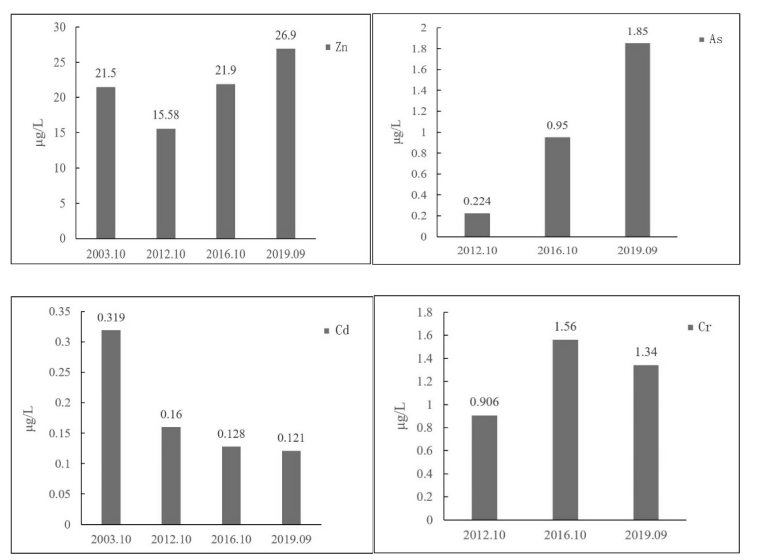

Figure 1. The change of COD, oil, inorganic nitrogen, phosphate, suspended solids, $\mathrm{Hg}, \mathrm{Cu}, \mathrm{Pb}, \mathrm{Zn}, \mathrm{Se}$, and $\mathrm{Cd}$ in the survey years

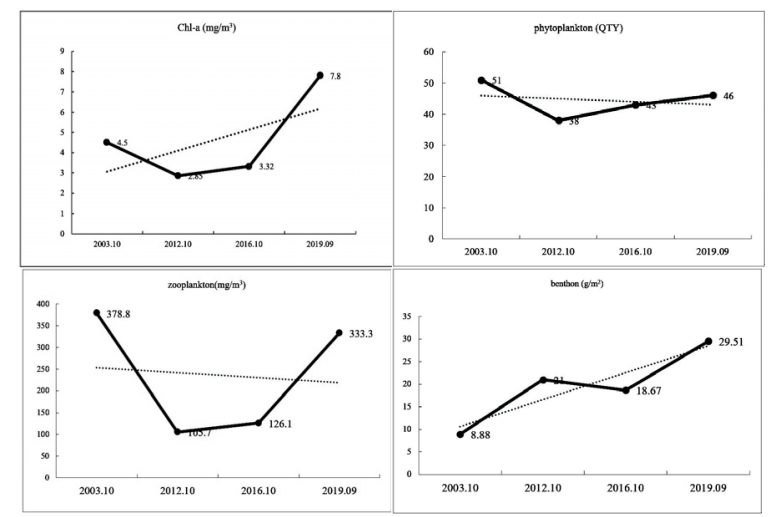

Figure 2. The change of chlorophyll, Zooplankton biomass and benthic biomass In the survey years

It can be seen that in the survey years, the area near the survey site had a poor water quality environment in 2012, and the water environment was eutrophic. The contents of heavy metals $\mathrm{Cu}$ and $\mathrm{Pb}$ were also higher. It can be seen from the ecological environment survey that the zooplankton biomass and chlorophyll content near the survey site are low. The increase of N, P and other nutrient contents mainly affects the primary productivity of the ocean, but the excess nutrients cannot be fully used by phytoplankton in the seawater ${ }^{[2]}$. As early as 1958, Redfield research has confirmed that only when the seawater is supplemented with an appropriate amount of nutrients, that is, when the N/P is 16: 1 (Redfield ratio) ${ }^{[4]}$, the effect of nutrients on primary productivity can be effective. The potential effect of unutilized nutrients is called eutrophication. At the same time, the input of heavy metal elements will inhibit the growth of phytoplankton ${ }^{[3]}$. According to Zhang's enrichment experiments in the Northwest Pacific, it can be proven that the inhibitory effect of heavy metals on phytoplankton is quite significant, and even exceeds the effect of nutrient on it ${ }^{[5]}$. In addition, the excessive input of heavy metals also has a certain negative effect on the growth of plankton and benthic organisms.

The Bohai Bay is a semi-closed bay. Tianjin coast is located in the bottom area of the Bohai Bay. Poor water exchange conditions with the outside world are not conducive to the spread of pollutants and selfpurification of the seawater. In addition, with urban development, port construction and the growing mariculture industry, the problem of eutrophication in the coastal waters of Tianjin has always been one of the important causes of water pollution ${ }^{[6]}$. What'more, it has been shown that atmospheric sedimentation is one of the important ways for various mixtures and chemical elements in the air to migrate from the atmosphere to the surface oceans ${ }^{[1]}$. The deterioration of air quality in Tianjin has caused the atmospheric pollution sink into the ocean, which may also cause changes in the marine environment.

In addition, since 2002, with the development of the reclamation project at Dongjiang, it has had a certain degree of impact on the seawater quality and marine ecological environment in the region. By the end of 2006, some internal barriers of the Beida breakwater project were completed. By 2009, the Beida breakwater project continued to be implemented Since 2014, there has been no change in the borderline of reclamation in Dongjiang, and there is no new reclamation.

According to the analysis of statistical results, from 2005 to 2013, it was a large-scale reclamation phase in Dongjiang, and no new reclamation has been done since 2014. The land formed by reclamation projects is used in the shipbuilding industry, power industry, ports, waterways, scientific research and teaching, roads and bridges, tourism infrastructure, anchorages and other industrial projects.

It can be seen that the development of the reclamation may be a cause of the changes in the water quality and ecological environment nearby this areas. The construction of the reclamation project will inevitably have a certain degree of impact on the marine environment in the surrounding waters of the project, and the project construction itself will disturb organisms in the marine environment. Reclamation projects occupy the environment that originally belonged to marine organisms, which directly leads to the reduction of marine biomass. At the same time, disturbances in construction operations and increased suspended solids concentrations caused by dredging operations will also affect marine organisms. As the reclamation area occupies a large area of shallow waters, it loses its marine attributes, causing the death of benthic organisms, fish eggs, larvae and juveniles living here, in addition, the benthic organisms in the sea area affected during the reclamation construction, Intertidal organisms and fishery resources have suffered a certain degree of loss.Reclamation of the project occupies part of the shallow waters and loses the natural attributes of the ocean. The marine organisms in the occupied sea area are lost, especially the benthic organisms. The reclamation construction also has a certain impact on the biological ecology of the surrounding seas, mainly In terms of diversity index, biomass, uniformity, and abundance reduction. Therefore, the reclamation construction has a certain degree of impact on the structure and function of the marine ecosystem at the location and nearby sea areas.

However, according to the results of the 2019 survey, the seawater quality and ecological environment at the survey sites were improved compared to 2003 and 2012, 
when the reclamation project was carried out, which shows that the marine environment can also be carried out through its own adjustment capabilities. A certain degree of restoration, after the reclamation project, the human impact on the marine environment will further expand. Therefore, while conducting such projects, environmental impact assessment and ecological assessment should be done well. Numerical simulation can be used. predict the environmental impact after the project is implemented. And it should calculate the economic benefits brought by the project and the negative impact of environmental damage, and ensure the relative balance between social development and environmental protection. We should scientifically develop marine resources.

\section{CONCLUSION}

The changes in the marine ecology of the waters near the Bohai Bay and Tianjin are closely related to the quality of seawater. In recent years, the deterioration of water quality near Tianjin may be related to surrounding reclamation projects. But the impact of reclamation activities on the marine ecological environment may reduce, with the end of the project. But it is difficult to recover to the pre-engineering environmental state, Human development should not be at the expense of the natural environment. Before the start of the marine project, calculate whether the economic benefits brought by the project are balanced with the losses caused by ecological degradation. What's more, we should carefully evaluate the social and natural values of the project, and make well ecological assessment and Repair work.

\section{ACKNOWLEDGMENTS}

This paper is one of the phased achievements of the National Nonprofit Institute Research Grants of Tianjin Research Institute for Study on integrated Remediation technology of Immobilized microorganisms in Polluted sea water (No. TKS190408).

\section{REFERENCES}

1. FENG S Z, LI F Q, LI S J. Introduction to Ocean Science $[\mathrm{M}]$.Beijing, Higher Education Press, 1999.130-136

2. GUO W D, ZHANG X M, YANG Y P, et al. 1998. Potential eutrophication assessment for Chinese coastal waters $[\mathrm{J}]$. Journal of Oceanography in Taiwan Strait, 1998, 17(1):64-70.

3. Paytan A, Mackey K R M, Chen Y, et al . Toxicity of atmospheric aerosols on marine phytoplankton $[\mathrm{J}]$. Proceedings of the National Academy of Sciences, 2009, 106( 12) : 4 601-4 605 .
4. Redfield A C, Ketchum B H, Recharsd F A. The influence of organisms on the composition of seawater[C]. New York: Interscience, 1963. 26-77.

5. Zhang $\mathrm{C}$, GAO $\mathrm{H} \mathrm{W}$, YAO $\mathrm{X} \mathrm{H}$, et al.Phytoplankton growth responses to Asian dust additions in the Northwest Pacific Ocean versus the Yellow Sea $[\mathrm{J}]$. Biogeosciences Disscutions, 2018, 15:749-765.

6. ZHOU X B, MEI P Y, PENG L L, et al. Contents and Potential Ecological Risk Assessment of Selected Heavy Metals in the Surface Sediments of Bohai Bay [J]. Ecology and Environmental Sciences, 2015, 24(3):452-456. 